\title{
Soil macrofauna density and diversity across a chronosequence of tropical forest restoration in Southeastern Brazil
}

\author{
N. T. Amazonas ${ }^{a *}$, R. A. G. Viani ${ }^{b}$, M. G. A. Rego ${ }^{b}$, F. F. Camargo , \\ R. T. Fujihara ${ }^{b}$ and O. A. Valsechi ${ }^{b}$ \\ aDepartamento de Ciências Florestais, Escola Superior de Agricultura “Luiz de Queiroz" - ESALQ, Universidade de \\ São Paulo - USP, Av. Pádua Dias, 11, Agronomia, CEP 13418-900, Piracicaba, SP, Brazil \\ ${ }^{b}$ Centro de Ciências Agrárias - CCA, Universidade Federal de São Carlos - UFSCar, Rodovia Anhanguera, Km 174, \\ Zona Rural, CEP 13600-970, Araras, SP, Brazil \\ 'Departamento de Ciências Florestais, Universidade Federal de Lavras - UFLA, Av. Doutor Sylvio Menicucci, 1001, \\ Aquenta Sol, CEP 37200-000, Lavras, MG, Brazil \\ *e-mail: namazonas@usp.br
}

Received: August 9, 2016 - Accepted: April 5, 2017 - Distributed: October 31, 2018

(With 4 figures)

\begin{abstract}
Edaphic macrofauna must be better studied if we want to take advantage of their full potential for the restoration of tropical ecosystems. We investigated changes in edaphic macrofauna density and diversity along a secondary succession chronosequence in the Atlantic Forest. Our results show some clear patterns of change in soil macrofauna along the chronosequence. Density did not increase along secondary succession, but was correlated with canopy cover. Diversity was characterized by high dominance of social insects and evenness among other groups. We conclude soil macrofauna has a high capacity to recolonize young forests and that its recovery is considerably fast compared to other ecosystem transformations.
\end{abstract}

Keywords: edaphic macrofauna, richness, bioindicators, Seasonal Semidecidual Forest.

\section{Densidade e diversidade da macrofauna edáfica em uma cronosequência de florestas tropicais em restauração no Sudeste do Brasil}

\begin{abstract}
Resumo
A macrofauna edáfica deve ser mais bem estudada se quisermos aproveitar todo o seu potencial para a restauração de ecossistemas tropicais. Nós investigamos as mudanças de densidade e diversidade da macrofauna edáfica em uma cronossequência durante a sucessão secundária na Mata Atlântica. Nossos resultados mostram padrões claros de mudança. A densidade não aumentou ao longo da sucessão secundária, mas foi correlacionada com a cobertura de dossel. A diversidade foi caracterizada pela alta dominância de insetos sociais e equidade entre os demais grupos. Nós concluímos que a macrofauna edáfica tem alta capacidade de recolonizar florestas jovens e que sua recuperação é relativamente rápida se comparada a outras transformações ecossistêmicas.
\end{abstract}

Palavras-chave: macrofauna edáfica, riqueza, bioindicadores, Floresta Estacional Semidecidual.

\section{Introduction}

Ecological restoration is now a global priority (Aronson and Alexander, 2013), and millions of hectares need to be restored in the tropics (Suding et al., 2015). Only in Brazil, 21.1 Mha of forests must be restored as legal a requirement (Soares-Filho et al., 2014). The shifts in composition and structure of vegetation during secondary succession through natural regeneration and forest restoration are fairly well-known, but knowledge associated with changes in soil macrofauna is still limited. Soil macrofauna succession has been studied much more in temperate than in subtropical and tropical areas (ex: Meloni and Varanda, 2015; Frouz and Ali, 2004; Brown et al., 2009; Machado et al., 2015). Ecological restoration implies in the recovery of not only vegetation, but the whole set of attributes of the original ecosystem, in which soil macrofauna is included. Thus, if we want to infer if forest ecosystems are really being restored by active restoration, we also need to evaluate whether vegetation structure recovery is able to imply in the reestablishment of the edaphic community.

Edaphic macrofauna have been considered as ecosystem engineers, because they affect soil resources availability and spatial distribution, acting by means of physical 
and biochemical processes, as well as creating habitats for other organisms, by the construction of biogenic structures and galleries, especially earthworms, ants and termites (Lavelle et al., 2016). Despite their key role in the functioning and development of ecosystems, edaphic macrofauna is still poorly explored in ecological restoration (Araújo et al., 2010; Jouquet et al., 2014) and not commonly included in evaluation of restoration success (Ruiz-Jaen and Aide, 2005; Wortley et al., 2013).

Our objective was to answer the following question: How soil macrofauna responds to changes in vegetation of forests undergoing active restoration? To answer this question, we investigated changes in macrofaunal community density and diversity in a chronosequence formed by a pasture, planted forests of different ages undergoing active restoration, and a secondary forest remnant as reference. Knowing that edaphic macrofauna responds to changes in vegetation structure during secondary succession, that canopy cover is a widespread indicator of early forest growth (Suganuma and Durigan, 2014), that planted forests are different from second growth forests during the early stages (Brockerhoff et al., 2013), and that great extensions of tropical forests are being actively restored worldwide through plantations, we hypothesized that soil macrofauna changes along with forest development in restoration areas in the Seasonal Semidecidual Forests of the Atlantic Forest biome.

\section{Material and Methods}

We conducted this study in Itu, São Paulo, Southeastern Brazil (Figure 1). Most of the sampling was carried out at Centro de Experimentos Florestais SOS Mata Atlântica $\left(23^{\circ} 20^{\prime} \mathrm{S}-47^{\circ} 20^{\prime} \mathrm{W}\right)$, an experimental station with several ongoing forest restoration initiatives. This experimental station comprises 526 ha (SOS Mata Atlântica, 2013), and it is located in a transition zone between Mata Atlantica [Atlantic Forest] (tropical forest) and Cerrado (savannah) biomes (Veloso et al., 1991). The predominant native vegetation type, at the experimental station, is the Seasonal Semideciduous Forest, a closed-canopy forest in Atlantic Forest biome with abundant deciduous and semi-deciduous trees and shrubs, which lose their leaves during the driest months (April to August). Annual precipitation is $1,331 \mathrm{~mm}$ and $40 \mathrm{~mm}$ during the driest months. Temperature ranges from 17.7 to $24.6{ }^{\circ} \mathrm{C}$ (Machado and Santos, 2003; EMBRAPA, 2014) with rainy summer and a dry winter (Alvares et al., 2013). There are four different types of soil in the region: clay loam dystrophic acrisols (chromic), rocky/coarse dystrophic acrisols (chromic), rocky/coarse dystrophic and eutrophic acrisols (chromic), and clayey dystrophic rhodic haplustox (Machado and Santos, 2003).

The chronosequence is represented by a pasture (dominated by Urochloa spp.), forest areas of different ages $(8,24,48$, and 84-month old plantations, representing a gradient of restoration stages) undergoing restoration, and a secondary forest for reference that has been protected from degradation/disturbance from many decades. The restoration sites were within a radius of $5 \mathrm{~km}$ and are all within the Centro de Experimentos Florestais SOS Mata Atlantica except the 8-month old plantation. Forest areas of different ages undergoing restoration were deforested and converted to coffee plantations several decades ago (SOS Mata Atlântica, 2013). Prior to restoration, these areas were converted to pastures dominated by Urochloa spp. The restoration technique applied was the native seedlings plantation, using a high diversity of native tree species at $3 \times 3 \mathrm{~m}$ spacing (density of 1,111 seedlings per hectare).

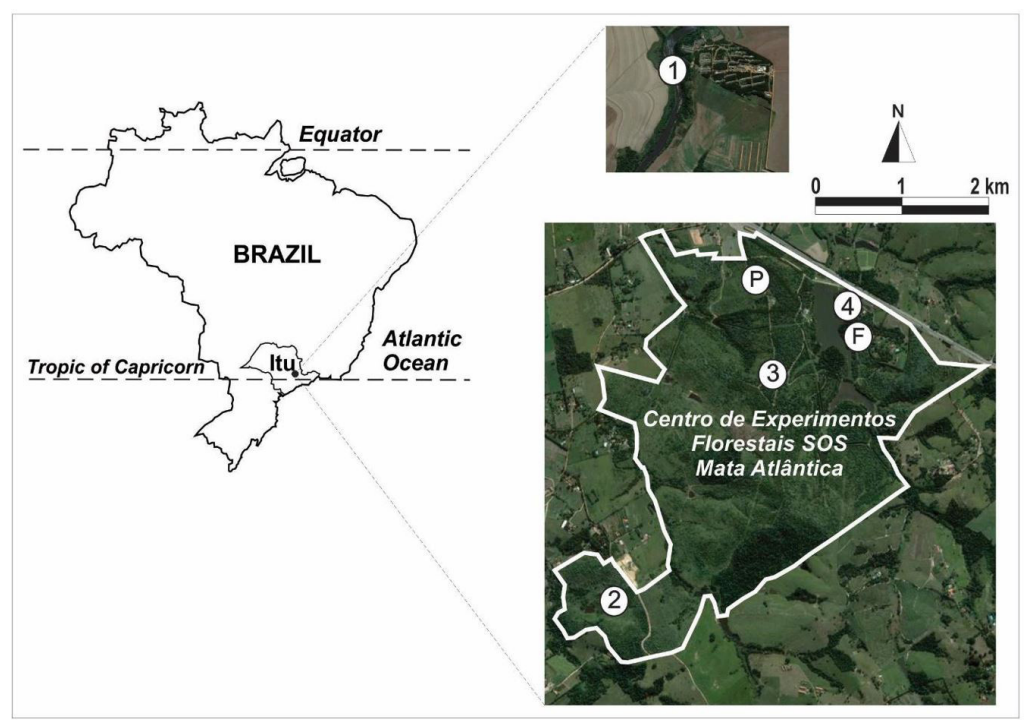

Figure 1. Location of the studied sites in Itu-SP, Southeastern Brazil. P: pasture, F: secondary reference forest; 1-4: forest restoration sites of 8(1), 24(2), 48(3) and 84(4)-month age. Site "1" is about $6 \mathrm{~km}$ away from the Centro de Experimentos Florestais SOS Mata Atlântica. 
During the first two years, grass control was performed in all restored areas using herbicide (glyphosate).

In each site, we randomly established five collection points and obtained data for canopy cover, litter biomass, and soil samples. At each collection point, we measured the percentage of canopy cover $(0-100 \%)$ using a spherical densiometer, and established $25 \times 25 \mathrm{~cm}$ plots for litter and soil collection. Litter samples were collected, dried at $65^{\circ} \mathrm{C}$ for $48 \mathrm{~h}$ and weighed to obtain dry litter biomass $\left(\mathrm{g} / \mathrm{m}^{2}\right)$. After litter removal, we collected soil samples, within the same plots, to the $15-\mathrm{cm}$ depth according to established protocols (Anderson and Ingram, 1993; Moreira et al., 2008). We decided to collect to the $15-\mathrm{cm}$ depth instead of $30 \mathrm{~cm}$ depth, because some studies have shown that the highest number of macrofauna organisms are found in the first $10 \mathrm{~cm}$ (Barreta et al., 2006; Rossi et al., 2006; Vega et al., 2014). Soil characteristics are available from a study performed in the same land (Gutierrez, 2016). All samples were collected in June 2014, during the cold dry season. Climatic data are available in a historic database for the municipality (EMBRAPA, 2017).

Macrofauna (sensu Swift et al., 1979) was carefully collected from soil samples and stored in containers using $70 \%$ alcohol. These individuals were later classified into the level of higher taxonomic groups (Triplehorn and Johnson, 2004; Ruiz and Lavelle, 2008), and counted to obtain their density (individuals $/ \mathrm{m}^{2}$ ). Since macrofauna was determined to the level of higher taxonomic groups and not to the species level, thus we used the number of individuals per taxonomic group to calculate density. The beta diversity index can be used to measure changes in species composition or species replacement rate along a gradient or transection. Beta diversity corresponds to the diversity between habitats or any other environmental variation and allows to describe how different or similar two communities are regarding species composition. Beta diversity will be higher when the different communities share less species. We calculated this index as a measure of diversity, to assess the differences of taxonomic groups among study sites. We used Whittaker's index $(\beta \mathrm{W})$, that ranges from 0 , when samples have the same species composition, to 2, the maximum difference in species composition (Whittaker 1960, 1972). The index is calculated as follows: $\beta \mathrm{W}=(\mathrm{c} / \mathrm{a})-1$, where $\mathrm{c}=$ total number of species recorded in sampled plots; $a=$ average number of species in samples.

We transformed density data using a Box-Cox transformation in order to meet ANOVA requirements. We used diversity data and then we used these data to build a rank-abundance curve to represent visually the richness and the evenness of taxonomic groups (Whittaker, 1960). We used the Analysis of Variance (ANOVA) to test differences in canopy cover, litter biomass, and soil macrofauna density and diversity across the vegetation chronosequence. For significant results, we performed the Tukey test $(\alpha=0.05)$ to compare means. Pearson's correlation analyses were used to test correlations between habitat characteristics and macrofaunal data. The above were performed in the Statistica 12 software $\left(\right.$ StatSoft $^{\circledR}$, Tulsa, OK, USA). A multivariate cluster analysis was done to identify similarities between sites, considering soil macrofauna density and composition through the Multi-Variate Statistical Package (MVSP) (Kovach Computing Services ${ }^{\circledR}$, Anglesey, Wales). In this analysis, we used a matrix with the number of individuals per taxonomic group in each plot across the chronosequence. The analysis of the cluster was done using the unweighted pair group method with the arithmetic mean (UPGMA) method and the Euclidean distance measure.

\section{Results}

The percentage of canopy cover increased along the chronosequence (ANOVA, $\mathrm{p}<0.001$ ). The pasture had low canopy cover, similarly to the 8-month old forest; the 24-month old forest had an intermediate value; and the 48- and 84-month-old forests and the reference forest had the highest percentages of canopy cover (Figure 2A). Litter biomass also increased along the chronosequence, except for the fact that the amount of biomass in the pasture
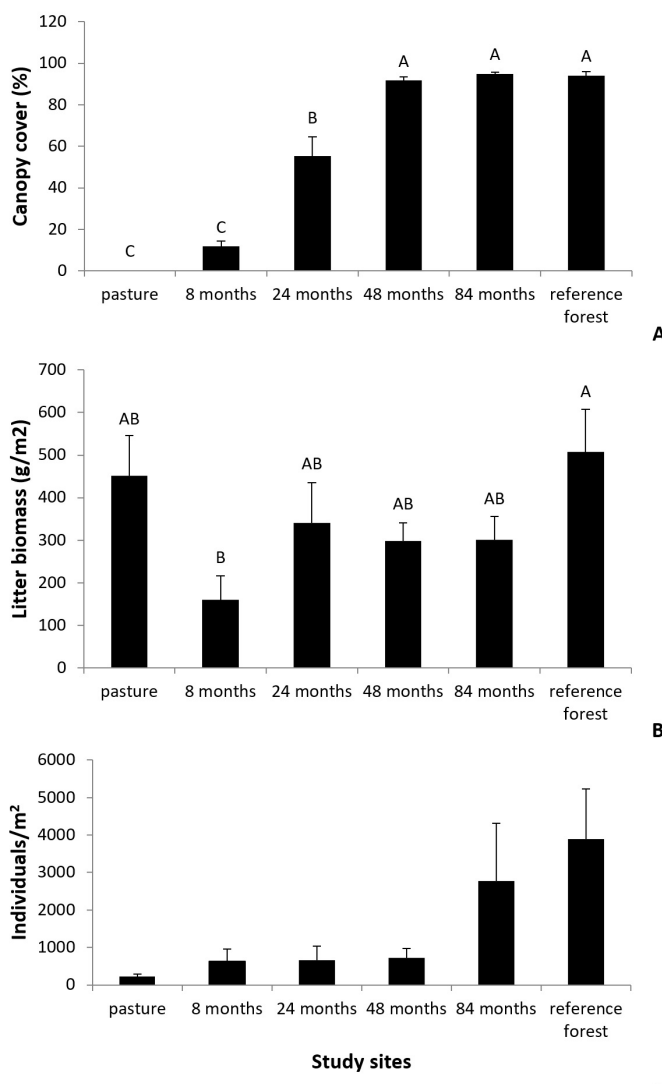

C

Figure 2. Mean (+ standard error) percentage of canopy cover (A), dry litter biomass (B), and soil macrofauna density (C) in studied sites (pasture, forest restoration sites of four different ages after tree seedling plantation, and secondary reference forest). Bars with distinct letters indicate differences in the Tukey test $(\mathrm{p}<0.05)$. 
was higher than the amount in forest restoration sites, but still lower than in the reference forest (Figure 2B). Edaphic macrofauna density did not increase linearly along the chronosequence. The reference ecosystem was the area with the highest values for this parameter (Figure 2C). We found positive correlation between canopy cover and macrofauna density (Pearson, $\mathrm{p}=0.017, \mathrm{r}=0.431$ ), but not between macrofauna density and dry litter biomass (Pearson, $\mathrm{p}=0.760, \mathrm{r}=0.058$ ) or diversity (Pearson, $\mathrm{p}=0.254, \mathrm{r}=0.214$ ).

The 2,778 collected individuals belong to 15 groups: Arachnidae, Auchennorhyncha, Blattaria, Coleoptera, Coleoptera larvae, Chilopoda, Dermaptera, Diplopoda, Diptera larvae, Formicidae, Gastropoda, Heteroptera, Isoptera, Lepidoptera larvae, Oligocheta, and Orthoptera. Of these, $2.5 \%$ were found in the pasture; $7 \%$ in the 8 -month old forest; $7.5 \%$ in the 24 -month old forest; $8 \%$ in the 48-month old forest; $31 \%$ in the 84 -month old forest; and $44 \%$ in the reference ecosystem. Most of the individuals collected were Formicidae ( $81.9 \%$ ), followed by Isoptera $(5.9 \%)$, and Coleoptera $(1.6 \%)$. We found a great variation in density in taxonomic groups in the sites, with no clear pattern across the chronosequence (Table 1).

The beta-diversity analysis showed great diversity of one group in all study sites (represented by Formicidae); intermediate abundance of six groups; and low abundance of seven taxonomic groups in our study sites. Overall, the 24- and the 84-month old forests had higher richness with 14 taxonomic groups each (Figure 3). Forests undergoing restoration had higher dominance of one group (Formicidae), intermediate dominance of four groups, and low dominance of the others. The reference forest is marked by high dominance of one group (Formicidae), which represents over $90 \%$ of individuals while the other groups account less than $1 \%$ together. In contrast, the overall dominance is lower in the pasture, where evenness is much higher and the relative abundance curve has a less steep slope (Figure 3). The cluster analysis grouped the reference forest and the oldest forest undergoing restoration; and also grouped the other restoration sites together, despite the slightly different composition of the 24-month old forest; and isolated the pasture (Figure 4).

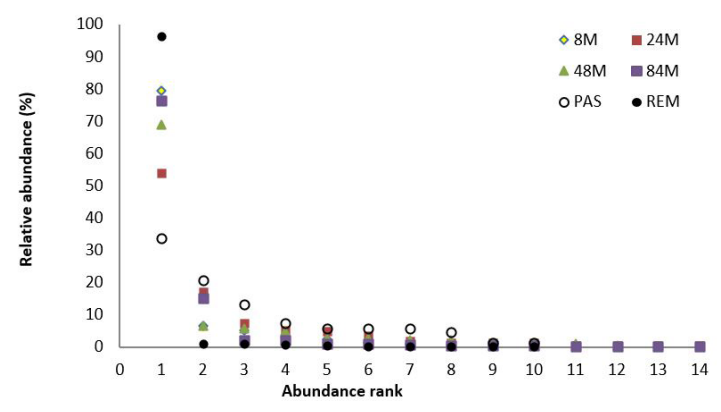

Figure 3. Rank-abundance curve for taxonomic groups of soil macrofauna found in the chronosequence studied. 8M=8-month-old; 24M=24-month-old; 48M=48-month-old; $84 \mathrm{M}=84$-month-old; REM=Reference forest; PAS=Pasture. Numbers 1-14 refer to the number of different taxonomic groups in each area.

Table 1. Number of individuals per taxonomic groups of soil macrofauna in studied sites.

\begin{tabular}{|c|c|c|c|c|c|c|c|c|}
\hline \multirow{3}{*}{$\begin{array}{c}\text { Taxonomic } \\
\text { groups }\end{array}$} & \multicolumn{6}{|c|}{ Study sites } & \multirow{3}{*}{ Total } & \multirow{3}{*}{$\begin{array}{c}\text { Relative } \\
\text { density } \\
(\%)\end{array}$} \\
\hline & \multirow[b]{2}{*}{ Pasture } & \multicolumn{4}{|c|}{ Forests undergoing restoration } & \multirow{2}{*}{$\begin{array}{c}\text { Reference } \\
\text { forest }\end{array}$} & & \\
\hline & & 8 & 24 & 48 & $\begin{array}{c}84 \\
\text { month-old }\end{array}$ & & & \\
\hline Arachnida & 0 & 3 & 1 & 15 & 2 & 4 & 25 & 0.9 \\
\hline Auchennorhyncha & 0 & 0 & 0 & 0 & 1 & 0 & 1 & 0.0 \\
\hline Blattaria & 1 & 0 & 3 & 11 & 2 & 1 & 18 & 0.6 \\
\hline Chilopoda & 0 & 1 & 0 & 3 & 7 & 12 & 23 & 0.8 \\
\hline Coleoptera & 9 & 13 & 10 & 5 & 4 & 3 & 44 & 1.6 \\
\hline Coleoptera larvae & 14 & 10 & 11 & 6 & 20 & 11 & 72 & 2.6 \\
\hline Dermaptera & 1 & 0 & 3 & 6 & 0 & 3 & 13 & 0.5 \\
\hline Diplopoda & 4 & 0 & 4 & 0 & 4 & 3 & 15 & 0.5 \\
\hline Formicidae & 23 & 158 & 112 & 155 & 659 & 1,168 & 2,275 & 81.9 \\
\hline Gastropoda & 0 & 0 & 1 & 0 & 2 & 2 & 5 & 0.2 \\
\hline Heteroptera & 4 & 5 & 3 & 13 & 3 & 0 & 28 & 1.0 \\
\hline Isoptera & 0 & 0 & 35 & 0 & 130 & 0 & 165 & 5.9 \\
\hline Lepidoptera larvae & 4 & 0 & 1 & 0 & 0 & 0 & 5 & 0.2 \\
\hline Oligocheta & 5 & 6 & 15 & 2 & 19 & 7 & 54 & 1.9 \\
\hline Orthoptera & 0 & 0 & 1 & 1 & 0 & 0 & 2 & 0.1 \\
\hline Diptera larvae & 0 & 2 & 0 & 3 & 5 & 0 & 10 & 0.4 \\
\hline Other invertebrates & 3 & 1 & 7 & 5 & 7 & 0 & 23 & 0.8 \\
\hline Total (individuals) & 68 & 199 & 207 & 225 & 865 & 1,214 & 2,778 & 100 \\
\hline
\end{tabular}




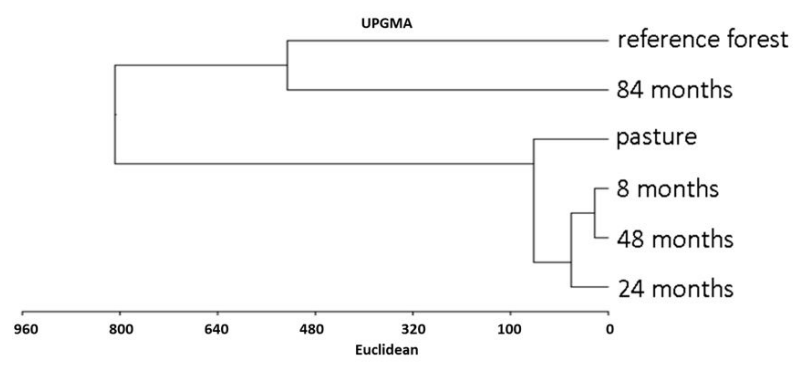

Figure 4. Clustering analysis for macrofauna density and diversity in the studied sites.

\section{Discussion}

We found clear patterns of change in soil macrofauna along the chronosequence studied. Soil macrofauna density did not increase linearly along the chronosequence, but it was correlated with increase in canopy cover. Overall diversity is characterized by high dominance of social insects and evenness among the other groups.

Vegetation cover helps avoiding the loss of soil macrofauna and stimulates the activity of ecosystem engineer functional groups: Oligochaeta, Formicidae, and Isoptera (Barros et al., 2003). Besides, canopy cover is an important ecological parameter directly related to litter production, which maintains microclimate conditions more stable. Our results corroborate our hypothesis that macrofauna changes along with changes in vegetation. Also, positive correlation between macrofauna density and canopy cover indicate that canopy cover can be considered a good parameter to infer macrofauna density in systems similar to our study sites.

In tropical degraded areas or secondary forests in early-successional stage, the edaphic fauna is exposed to a stressful environment, nutrient poor conditions, compacted soils, and unstable conditions of moisture and temperature. These features change along secondary succession as soils recover. Soil macrofauna responds to changes in vegetation along secondary succession (Meloni and Varanda, 2015), such as structural changes (Decaens et al., 1998), increases in plant biomass, and vegetation diversity and complexity (Menezes et al., 2009), and to increases in organic matter (Burger and Knoll, 2011). The conditions that soil organisms are subjected to are very different, with the open area with great litter biomass in the pasture in one extreme; the forested areas of increasingly higher canopy cover and litter biomass in forests undergoing restoration in the middle; and the shaded area with greatest litter biomass in the reference forest at the other extreme. These different environments and amounts of resources cause soil macrofauna to vary in density and diversity. We did not find a linear increase in macrofauna density as forests age towards values found in the reference ecosystem, which is not in accordance with other studies (Merlim, 2005; Meloni and Varanda, 2015). The abundance and diversity of macrofauna can be influenced by variation in litter quantity and quality (Sayer et al., 2010). The high amount of litter in the pasture site may have biased the results explaining why soil macrofauna was not correlated to litter biomass.

Ants and termites were the most abundant group in all sites. This is a common pattern in the literature, but is also pointed out as a possible result of the sampling method (TSBF) that could overestimate the abundance of these groups of aggregated distribution if sampling is done near nests. The high abundance of Formicidae is predominant in most terrestrial ecosystems (Machado et al., 2015), especially in tropical forests. This group was found to be the most numerous in studies done in the Atlantic Forest (Toledo, 2003; Menezes et al., 2009).

We did not classify ants into morphospecies and functional groups, but the gradual increase of individuals in the chronosequence may indicate greater species richness. Leal et al. (2012) states that fragment size and tree density are important variables predicting species richness and functional diversity. Also, the substitution of species and changes in the ecosystem vegetation type can offer more sites for nesting, like undecomposed twigs that have fallen on the soil (de Souza et al., 2012), besides the increase in quality and quantity of feeding resources.

Ants may promote the improvement of physical and chemical characteristics of soils (Ruiz and Lavelle, 2008), increasing organic matter, nitrogen, phosphorus, and potassium (Carlson and Whitford, 1991; Petal, 1978). Their presence may facilitate the establishment of other functional groups in the ecosystem, such as the mutualist associations with scales, aphids, and cicadas (Sternorrhyncha and Auchennorrhyncha) (Lee, 1985; Way and Khoo, 1992).

Isoptera was the second most numerous taxa. Formicidae's and Isoptera's dominance in this forest type was previously reported. Previous research reported a higher number of ants and termites in the dry season compared to the wet season, which might explain our results found, since we have collected during the dry season (Menezes et al., 2009).

The number of Coleoptera decreased along the gradient, being more numerous in younger forests. A similar pattern was found in the Araucaria Forest, another forest type of the Atlantic Forest biome (Merlim, 2005). Oligochaeta generally represents the largest portion of animal living biomass in soil (Lee, 1985), but they are known to migrate 
vertically deeper in soils during dry periods (Bouche and Gardner, 1984), meaning that density and diversity could be higher if we had sampled in the wet period. Other studies have found lower abundance of earthworms in dry periods (Menezes et al., 2009). This group was equally present in all areas. Worms are one of the most active components of soil macrofauna, affect positively the growth of plants, perform biological control, decompose organic matter and promote not only nutrient cycling but also the formation and aggregation of soil particles. Despite their importance and active role, the Oligochaeta are subjected to habitat perturbation and contamination.

There was a very low abundance of Chilopoda compared to other groups. This taxon is commonly more abundant in older ecosystems, which is in accordance to the fact that these organisms are mainly found in litter and are more common in ecosystems with high canopy cover (Ruiz and Lavelle, 2008). The oldest restoration might have the greatest diversity of predators and a more complex trophic structure (Begon et al., 2006). Considering that predators exert strong influence on species abundance, their presence could be a reflex of the increasing structural complexity of the vegetation.

The clustering analysis grouped the 84-month-old forest with the reference forest. This may indicate that the soil macrofauna community is being recovered, and that 7 years after tree seedlings plantation, a forest restoration site is more similar to the reference ecosystems in terms of soil macrofauna than it is to younger restoration sites. Some attributes of the ecosystem such as nutrient cycles may take a long time to be restored. At this same forest type, a forest restoration site 52 years old had not its nitrogen cycling restored yet (Amazonas et al., 2011).

In addition, even some general vegetation attributes in tropical forests, such as tree density and density and richness of saplings, may take a longer time to be restored if compared to reference ecosystems (Suganuma and Durigan, 2014). However, our results suggest that soil macrofauna may take less time to be restored [see also (Gomes et al., 2014) for ants] and that this is intrinsically related to the reestablishment of canopy cover and litter deposition.

We conclude that young forests originated from active restoration promote the recovery of soil macrofauna density and diversity, even before the restoration of many attributes of vegetation and ecosystem nutrient cycling. Also, our results suggest that canopy cover of young restoration plantations can be used as a predictor of soil macrofauna density in this forest type. Although these results are clear in our study, future research is necessary to investigate changes in soil macrofauna during forest restoration in other forest types, the role some specific groups within orders and families play as bioindicators, and to deeper explain how changes in litter deposition and canopy cover affect each soil macrofauna group.

\section{Acknowledgements}

We are thankful to the Centro de Experimentos Florestais SOS Mata Atlântica for all field support. We also thank Dr. Flávia M. S. Moura and Dr. Virgínia F. P. Araújo for their comments on previous versions of the manuscript. This research was supported by grant \#2013/50718-5, São Paulo Research Foundation (FAPESP).

\section{References}

ALVARES, C.A., STAPE, J.L., SENTELHAS, P.C., GONÇALVES, J.L.M. and SPAROVEK, G., 2013. Köppen's climate classification map for Brazil. Meteorologische Zeitschrift, vol. 22, no. 6, pp. 711-728. http://dx.doi.org/10.1127/0941-2948/2013/0507.

AMAZONAS, N.T., MARTINELLI, L.A., PICCOLO, M.C. and RODRIGUES, R.R., 2011. Nitrogen dynamics during ecosystem development in tropical forest restoration. Forest Ecology and Management, vol. 262, no. 8, pp. 1551-1557. http://dx.doi. org/10.1016/j.foreco.2011.07.003.

ANDERSON, J.M. and INGRAM, J.S., 1993. Tropical soil biology and fertility: a handbook of methods. 2. ed. Wallingford: Commonwealth Agricultural Bureau. 221 p.

ARAÚJO, V.F.P., BANDEIRA, A.G. and VASCONCELLOS, A., 2010. Abundance and stratification of soil macroarthropods in a Caatinga Forest in Northeast Brazil. Brazilian Journal of Biology $=$ Revista Brasileira de Biologia, vol. 70, no. 3, suppl., pp. 737-746. PMid:21085780. http://dx.doi.org/10.1590/S151969842010000400006

ARONSON, J. and ALEXANDER, S., 2013. Ecosystem restoration is now a global priority: time to roll up our sleeves. Restoration Ecology, vol. 21, no. 3, pp. 293-296. http://dx.doi.org/10.1111/ rec.12011.

BARRETA, D., SANTOS, J.C.P., BERTOL, I., ALVES, M.V., MANFOI, A.F. and BARRETA, C.R.D.M., 2006. Efeito do cultivo do solo sobre a diversidade da fauna edáfica no planalto sul catarinense. Revista de Ciências Agroveterinárias, vol. 5, no. 2, pp. 108-117.

BARROS, E., NEVES, A., BLANCHART, E., FERNANDES, E.C.M., WANDELLI, E. and LAVELLE, P., 2003. Development of the soil macrofauna community under silvopastoral and agrosilvicultural systems in Amazonia. Pedobiologia, vol. 47, no. 3, pp. 273-280. http://dx.doi.org/10.1078/0031-4056-00190.

BEGON, M., TOWNSEND, C.R. and HARPER, J.L., 2006. Ecology: from individuals to ecosystems. 4th ed. Malden: Blackwell Publishing. $752 \mathrm{p}$.

BOUCHÉ, M. B., and GARDNER, R. H., 1984. Earthworm functions. VIII: population estimation techniques. Revue d'Ecologie et de Biologie du Sol, vol. 21, no. 1, pp. 37-63.

BROCKERHOFF, E.G., JACTEL, H., PARROTTA, J.A. and FERRAZ, S.F.B., 2013. Role of eucalypt and other planted forests in biodiversity conservation and the provision of biodiversityrelated ecosystem services. Forest Ecology and Management, vol. 301, pp. 43-50. http://dx.doi.org/10.1016/j.foreco.2012.09.018.

BROWN, G.G., MASCHIO, W. and FROUFE, L.C.M., 2009. Macrofauna do solo em sistemas agroflorestais e Mata Atlântica em regeneração nos Municípios de Barra do Turvo, SP, e Adrianópolis, PR. Documentos. Embrapa Florestas, vol. 184, pp. 1-51. 
BURGER, D. and KNOLL, R., 2011. Influence of soil macrofauna on soil micromorphology and soil chemistry in Central Amazonian agricultural and forest ecosystems. In: Proceedings of the Workshop "Low-Input Intensification of Agriculture - Opportunities and Barriers in Developing Countries", 10 October, Karlsruhe, Germany. Karlsruhe: Karlsruhe Institute of Technology, pp. 83-102.

CARLSON, S.R. and WHITFORD, W.G., 1991. Ant mound influence on vegetation and soils in a semiarid mountain ecosystem. American Midland Naturalist, vol. 126, no. 1, pp. 125-139. http:// dx.doi.org/10.2307/2426157.

DECAENS, T., DUTOIT, T., ALARD, D. and LAVELLE, P., 1998. Factors influencing soil macrofaunal communities in post-pastoral successions of western France. Applied Soil Ecology, vol. 9, no. 1-3, pp. 361-367. http://dx.doi.org/10.1016/S0929-1393(98)00090-0.

EMPRESA BRASILEIRA DE PESQUISA AGROPECUÁRIA - EMBRAPA, 2014 [viewed 15 July 2014]. Banco de dados climáticos do Brasil [online]. Brasília: EMBRAPA. Available from: bdclima.cnpm.embrapa.br/resultados/balanco.php? $\mathrm{UF}=\& \mathrm{COD}=355$

EMPRESA BRASILEIRA DE PESQUISA AGROPECUÁRIA - EMBRAPA, 2017 [viewed 23 March 2017]. Banco de dados climáticos do Brasil [online]. Brasília: EMBRAPA. Available from: cnpm.embrapa.br/projetos/bdclima/balanco/resultados/ $\mathrm{sp} / 355 /$ balanco.html

FROUZ, J. and ALI, A., 2004. Soil macroinvertebrates along a successional gradient in central Florida. The Florida Entomologist, vol. 87, no. 3, pp. 886-390. http://dx.doi.org/10.1653/00154040(2004)087[0386:SMAASG]2.0.CO;2.

FUNDAÇÃO SOS MATA ATLÂNTICA - SOS MATA ATLÂNTICA, 2013. Centro de Experimentos Florestais SOS Mata Atlântica - Brasil Kirin, Relatório Anual 2012. São Paulo: SOS Mata Atlântica.

GOMES, E.F.C., RIBEIRO, G.T., SOUZA, T.M.S. and SOUSASOUTO, L., 2014. Ant assemblages (Hymenoptera: Formicidae) in three different stages of forest regeneration in a fragment of Atlantic Forest in Sergipe, Brazil. Sociobiology, vol. 61, no. 3, pp. 250-257. http://dx.doi.org/10.13102/sociobiology.v61i3.250-257.

GUTIERREZ, A. B., 2016. Efeito de atributos fisicos e químicos do solo sobre o desenvolvimento da comunidade florestal em restauração. Araras: Centro de Ciências Agrárias, Universidade Federal de São Carlos. Trabalho de Conclusão de Curso.

JOUQUET, P., BLANCHART, E. and CAPOWIEZ, Y., 2014. Utilization of earthworms and termites for the restoration of ecosystem functioning. Applied Soil Ecology, vol. 73, pp. 34-40. http://dx.doi.org/10.1016/j.apsoil.2013.08.004.

LAVELLE, P., SPAIN, A., BLOUIN, M., BROWN, G., DECAËNS, T., GRIMALDI, M., JIMÉNEZ, J.J., MCKEY, D., MATHIEU, J., VELASQUEZ, E. and ZANGERLÉ, A., 2016. Ecosystem Engineers in a Self-organized Soil: A Review of Concepts and Future Research Questions. Soil Science, vol. 181, no. 3/4, pp. 91-109. http://dx.doi.org/10.1097/SS.0000000000000155.

LEAL, I.R., FILGUEIRAS, B.K.C., GOMES, J.P., IANNUZZI, L. and ANDERSEN, A.N., 2012. Effects of habitat fragmentation on ant richness and functional composition in Brazilian Atlantic forest. Biodiversity and Conservation, vol. 21, no. 7, pp. 16871701. http://dx.doi.org/10.1007/s10531-012-0271-9.

LEE, K.E., 1985. Earthworms: their ecology and relationships with soil and land use. Adelaide: Academic Press. 411 p.

MACHADO, D.L., PEREIRA, M.G., CORREIA, M.E.F., DINIZ, A.R. and MENEZES, C.E.G., 2015. Soil fauna in successional dynamics of Atlantic Forest in semi-deciduous seasonal forest in the basin of river 'Paraíba do Sul', Rio de Janeiro State. Ciência Florestal, vol. 25, no. 1, pp. 91-106. http://dx.doi.org/10.1590/1980509820152505091.

MACHADO, L.A. and SANTOS, M.T.N., 2003. Estudo de impacto ambiental EIA/RIMA: loteamento fechado Parque Terras de Santa Cecília. Itu. Processo SMA/DAIA 13.699/2002. vol. 1.

MELONI, F. and VARANDA, E.M., 2015. Litter and soil arthropod colonization in reforested semi-deciduous seasonal Atlantic forests. Restoration Ecology, vol. 23, no. 5, pp. 690-697. http://dx.doi. org/10.1111/rec.12236.

MENEZES, C.E.G., CORREIA, M.E.F., PEREIRA, M.G., BATISTA, I., RODRIGUES, K.M., COUTO, W.H., ANJOS, L.H.C. and OLIVEIRA, I.P., 2009. Macrofauna edáfica em estádios sucessionais de Floresta Estacional Semidecidual e pastagem mista em Pinheiral (RJ). Revista Brasileira de Ciência do Solo, vol. 33, no. 6, pp. 1647-1656. http://dx.doi.org/10.1590/ S0100-06832009000600013.

MERLIM, A.O., 2005. Macrofauna edáfica em ecossistemas preservados e degradados de araucária no parque Estadual de Campos do Jordão, SP. Piracicaba: Universidade de São Paulo, 89 p. Dissertação de Mestrado.

MOREIRA, F.M.S., HUISING, E.J. and BIGNELL, D., 2008. A handbook of tropical soil biology: sampling and characterization of below-ground biodiversity. London: Routledge. $256 \mathrm{p}$.

PETAL, J., 1978. The role of ants in ecosystems. In: M.V. BRIAN, ed. Production ecology of ants and termites. Cambridge: Cambridge University Press, pp. 293-325.

ROSSI, J.P., MATHIEU, J., COOPER, M. and GRIMALDI, M., 2006. Soil macrofaunal biodiversity in Amazonian pastures: matching sampling with patterns. Soil Biology \& Biochemistry, vol. 38, no. 8, pp. 2178-2187. http://dx.doi.org/10.1016/j.soilbio.2006.01.020.

RUIZ, N. and LAVELLE, P., 2008. Soil macrofauna field manual: technical level. Rome: Food and Agriculture Organization of the United Nations. $101 \mathrm{p}$.

RUIZ-JAEN, M.C. and AIDE, M.T., 2005. Restoration success: how is it being measured? Restoration Ecology, vol. 13, no. 3, pp. 569-577. http://dx.doi.org/10.1111/j.1526-100X.2005.00072.x.

SAYER, E.J., SUTCLIFFE, L.M., ROSS, R.I. and TANNER, E.V., 2010. Arthropod abundance and diversity in a lowland tropical forest floor in Panama: the role of habitat space vs. nutrient concentrations. Biotropica, vol. 42, no. 2, pp. 194-200. http:// dx.doi.org/10.1111/j.1744-7429.2009.00576.x.

SOARES-FILHO, B., RAJÃO, R., MACEDO, M., CARNEIRO, A., COSTA, W., COE, M., RODRIGUES, H. and ALENCAR, A., 2014. Cracking Brazil's forest code. Science, vol. 344, no. 6182, pp. 363-364. PMid:24763575. http://dx.doi.org/10.1126/ science. 1246663 .

SOUZA, D.R., FERNANDES, T.T., NASCIMENTO, J.R., SUGUITURU, S.S. and MORINI, M.S.C., 2012. Characterization of ant communities (Hymenoptera: Formicidae) in twigs in the leaf litter of the Atlantic Rainforest and Eucalyptus trees in the Southeast Region of Brazil. Psyche, vol. 2012, pp. 1-12. http:// dx.doi.org/10.1155/2012/532768.

SUDING, K., HIGGS, E., PALMER, M., CALLICOTT, J.B., ANDERSON, C.B., BAKER, M., GUTRICH, J.J., HONDULA, K.L., LAFEVOR, M.C., LARSON, B.M., RANDALL, A., RUHL, J.B. and SCHWARTZ, K.Z., 2015. Committing to 
ecological restoration. Science, vol. 348, no. 6235, pp. 638-640. PMid:25953995. http://dx.doi.org/10.1126/science.aaa4216.

SUGANUMA, M.S. and DURIGAN, G., 2014. Indicators of restoration success in riparian tropical forests using multiple reference ecosystems. Restoration Ecology, vol. 23, no. 3, pp. 238-251. http://dx.doi.org/10.1111/rec.12168.

SWIFT, M.J., HEAL, O.W. and ANDERSON, J.M., 1979. Decomposition in terrestrial ecosystems. Berkeley: University of California Press. 372 p.

TOLEDO, L. O., 2003. Aporte de serapilheira, fauna edáfica e taxa de decomposição em áreas de floresta secundária no municipio de Pinheiral, RJ. Seropédica: Universidade Federal Rural do Rio de Janeiro. Dissertação de Mestrado.

TRIPLEHORN, C.A. and JOHNSON, N.F., 2004. Borror and DeLong's Introduction to the study of insects. $7 \mathrm{th}$ ed. Stamford: Cengage Learning. $888 \mathrm{p}$.

VEGA, A.M., HERRERA, R.S., RODRÍGUEZ, S.S., LAMELA, L. and SANTANA, A.A., 2014. Evaluation of the edaphic macrofauna in a silvopastoral system in Cauto Valley, Cuba. Canadian Journal of Agricultural Science, vol. 48, no. 2, pp. 189-193.

VELOSO, H.P., RANGEL FILHO, A.L.R. and LIMA, J.C.A., 1991. Classificação da vegetação brasileira adaptada a um sistema universal. Rio de Janeiro: IBGE.

WAY, M.J. and KHOO, K.C., 1992. Role of ants in pest management. Annual Review of Entomology, vol. 37, no. 1, pp. 479-503. http:// dx.doi.org/10.1146/annurev.en.37.010192.002403.

WHITTAKER, R.H., 1960. Vegetation of the Siskiyou Mountains, Oregon and California. Ecological Monographs, vol. 30, no. 3, pp. 279-338. http://dx.doi.org/10.2307/1943563.

WHITTAKER, R.H., 1972. Evolution and measurement of species diversity. Taxon, vol. 21, no. 2/3, pp. 213-251. http:// dx.doi.org/10.2307/1218190.

WORTLEY, L., HERO, J.M. and HOWES, M., 2013. Evaluating ecological restoration success: a review of the literature. Restoration Ecology, vol. 21, no. 5, pp. 537-543. http://dx.doi.org/10.1111/ rec. 12028 . 